\title{
FENOMENA MEROKOK PADA REMAJA PUTRI: STUDI KUALITATIF
}

\author{
Devie Hangriani Patana ${ }^{1^{*}}$, Yunus Elon ${ }^{2}$ \\ ${ }^{1}$ Universitas Advent Indonesia \\ ${ }^{2}$ Universitas Advent Indonesia \\ Alamat korespondensi : (hangrianidvie@gmail.com/085224241772)
}

\begin{abstract}
Abstrak
Merokok merupakan salah satu fenomena gaya hidup pada kebanyakan orang saat ini. Kebiasaan merokok umumnya dilakukan pada saat usia remaja. Penelitian ini bertujuan untuk mengetahui fenomena merokok pada remaja putri. Penelitian ini merupakan penelitian kualitatif yang bersifat deskriptif dengan menggunakan metode snowball sampling. Analisis data dilakukan dengan model analisis interaktif yang terdiri dari 3 komponen, yaitu memilih data, paparan data, dan menarik kesimpulan hasil deskripsi. Informan dalam penelitian ini adalah 10 orang remaja putri yang merupakan siswi SMA yang berdomisili di Kecamatan Parongpong. Pengumpulan data dilakukan dilakukan dengan metode wawancara. Hasil penelitian menunjukkan fenomena merokok pada remaja putri antara lain hal yang menjadi alasan informan merokok yaitu; pengaruh teman, ingin coba-coba, penasaran dan iseng. Hal yang dirasakan saat pertama kali merokok yaitu; pusing, batuk, pahit dan tidak enak. Respon teman mengetahui informan merokok yaitu; biasa saja, tidak merespon, dan tidak menyangka. Hal yang dirasakan informan setelah merokok antara lain; nyaman, puas, enak dan biasa saja. Tanggapan informan mengenai rokok sudah menjadi suatu kebutuhan yaitu; sebagai pelarian, penghilang stress, lagi santai, dan saat berkumpul bersama teman. Pandangan informan terhadap remaja putri yang merokok yaitu; "biasa saja", "illfeel", "tidak baik" dan "jelek". Perlu adanya kerjasama lintas sektoral untuk meningkatkan tentang bahaya rokok.
\end{abstract}

Kata Kunci: Fenomena, Merokok, Remaja Putri

\section{PENDAHULUAN}

Merokok merupakan salah satu fenomena buruk yang sampai saat ini belum dapat diselesaikan. Berbagai upaya telah dilakukan oleh pemerintah, pemerhati kesehatan serta organisasi-organisasi kesehatan dan kemanusian untuk mengurangi jumlah perokok aktif dimasyarakat, namun sampai pada saat ini jumlah perokok terus betambah dengan usia yang sangat muda. Menurut penelitian yang dilakukan oleh Elon dan Evelin, (2019) usia perokok dini terus meningkat yang bahkan dimulai di usia sekolah dasar dan sekolah menengah pertama. Rokok mengandung zat psikoaktif yang bernama nikotin yang dapat menimbulkan efek kesenangan sementara di otak yang membuat seseorang mengalami ketergantungan.

Menurut Rochka, (2019) perilaku merokok merupakan perilaku yang membahayakan urtuk kesehatan, tetapi masih banyak orang yang melakukan kebiasaan tersebut. Perilaku merokok dilihat dari berbagai sudut pandang sangat merugikan, baik untuk diri sendiri maupun orang disekelilingnya. Merokok juga dapat menyebabkan beberapa masalah kesehatan yang cukup serius dan bahkan menyebabkan kematian. Namun masih banyaknya masyarakat yang belum dan kurang akan pemahaman mengenai masalah yang dapat ditimbulkan oleh rokok itu sendiri, sehingga perilaku merokok masih belum bisa dihilangkan terlebih lagi pada generasi muda saat ini.

Kebanyakan perokok mulai merokok saat di usia remaja. Ini karena perkembangan usia dan pribadi biasanya mendorong seseorang cenderung mencoba berbagai hal termasuk hal yang negative seperti merokok. Sikap ingin mencoba beberapa hal baru biasanya di lakukan pada saat usia remaja, salah satunya menghisap rokok (Ali, 2009).

WHO (2015) menunjukkan prevalensi merokok pada wanita muda pada tahun 2009 adalah $6,4 \%$ dan menjadi $8 \%$ pada tahun 2014. Dari hasil data Riskesdas (2018) menunjukkan bahwa prevelensi merokok pada remaja usia 10-18 tahun mengalami peningkatan dari tahun $2013(7,20 \%)$ ke tahun $2018(9,10 \%)$.

Ketika perempuan merokok, pandangan aneh dapat terlontar dari mata masyarakat disekitarnya. Berbagai penilaian moral miring sangat muda terlontar bagi perempuan yang melakukan kegiatan merokok di depan umum. Anggapan buruk seperti perempuan "tidak benar", perempuan "nakal", perempuan "liar", bahkan perempuan "brandal" dapat mudah 
terbersit dalam benak masyarakat ketika melihat seorang perempuan perokok. Terlebih lagi penggambaran perempuan merokok dalam media yang cenderung negative (Handayani, dkk., 2012). Khususnya di Indonesia, merokok merupakan hal yang tabu dan tidak pantas di lakukan oleh perempuan. Fenomena merokok pada wanita, cenderung diberi kesan negative oleh masyarakat sekitar.

Surya (2010) mengatakan alasan remaja merokok ada yang sebagai penghilang kecemasan karena suka aromanya dan sebagian karena ingin menyesuaikan diri dan di terima oleh lingkungan. Adian dan Pratama (2013) juga mengatakan penyebab perilaku merokok pada remaja karena maraknya iklan rokok.

Ketertarikan generasi muda untuk mencoba rokok sesungguhnya di dorong oleh sifat-sifat positif alami generasi muda, yaitu: Perasaan ingin tahu, Perasaan ingin diakui lebih berani oleh lingkungannya, Perasaan ingin dianggap lebih hebat dan lebih dewasa dibanding teman dewasa dan Perasaan setia kawan, senasib sepenanggungan. Ke empat hal ini dapat mendorong para remaja untuk berkembang dan maju apabila dimanfaatkan untuk hal positif. Bila ke empat hal tersebut berkembang kearah yang keliru yaitu merokok akan menyebabkan penderitaan dan kebodohan Partodiharjo, (2012).

Penelitian yang dilakukan oleh Martini (2014), menyatakan bahwa perilaku merokok pada remaja putri merupakan simbol sikap yang keren, merasa berbeda dari remaja putri lainnya, membuat remaja putri bebas dari aturan dan bisa mendapat kenikmatan dan juga rokok bisa menjadi teman ketika terjadi perasaan kosong atau kesepian.

Berdasarkan latar belakang masalah yang telah dipaparkan diatas, maka peneliti tertarik melakukan penelitian fenomena merokok dikalangan remaja putri.

\section{BAHAN DAN METODE}

\section{Lokasi, Populasi, Sampel}

Penelitian ini menggunakan metode kualitatif yang merupakan suatu prosedur penelitian yang menggunakan data deskriptif berupa kata-kata tertulis atau lisan dari orangorang dan pelaku yang dapat diamati (Fitra dan Lutfiyah, 2017). Penelitian kualitatif yang bersifat deskriptif ini bertujuan untuk membuat deskripsi serta hubungan antar fenomena yang diselidiki.

Penelitian ini dilakukan di beberapa lokasi di Desa Cihanjuang dan Desa Karyawangi, Kecamatan Parongpong. Waktu penelitian dilakukan selama 18 hari. Waktu penelitian tersebut merujuk pada jangka waktu pencarian dan pendekatan terhadap informan. Proses wawancara dilakukan di rumah informan dan di tempat-tempat informan biasa berkumpul dengan teman-teman informan. Subjek dalam penelitian ini adalah remaja putri di Desa Cihanjuang dan Desa Karyawangi Kecamatan Parongpong yang melakukan perilaku merokok. Jumlah subjek pada penelitian ini berjumlah 10 orang remaja putri dengan kriteria:

1. Remaja putri yang berusia 15-20 tahun yang merupakan siswi SMA.

2. Remaja putri yang berperilaku merokok.

3. Bersedia menjadi partisipan.

Selain menggunakan kriteria tersebut, proses penentuan pada subjek dilakukan dengan metode snowball sampling yaitu peneliti menemukan satu informan yang merekomendasikan atau membawa informan lain untuk dijadikan subjek penelitian. Teknik pengumpulan data meliputi wawancara dan observasi serta instrument penelitian yang digunakan adalah pedoman wawancara dan alat perekam suara. Sebelumnya penelitian ini telah mendapatkan keterangan layak etik, dengan No.029/KEPK-FIK.UNAI/EC/X19. Setelah informan menandatangani informed consent, peneliti melakukan proses wawancara.

\section{Pengumpulan Data}

1. Data sekunder adalah yang diperoleh dari dokumen-dokumen grafis (tabel, catatan) foto-foto, benda-benda lain yang dapat memperkaya data sekunder.

2. Data primer adalah data yang diperoleh dari respondeng yang berada di lokasi penelitian. (Rukajat, 2018).

\section{Pengolahan Data}

Data yang dikumpulkan selanjutnya diklasifikasikan dan diorganisasikan secara logis menurut rancangan penelitian yang telah ditetapkan. Pengolahan data diantaranya adalah:

1. Data yang telah terkumpul perlu diolah dulu.

2. Menyederhanakan seluruh data yang terkumpul.

3. Menyajikannya dalam susunan yang sistematis.

4. Dianalisis berdasarkan teknik yang telah ditetapkan. (Fitra\&Luthfiyah, 2017).

\section{Analisis Data}

Teknik analisis data yang digunakan adalah analisis deskriptif, yaitu suatu upaya untuk mendeskripsikan secara menyeluruh focus kajian penelitian melalui interpretasi peneliti. Dengan demikian, analisis data 
merupakan serangkaian langkah untuk mengurai data menjadi bagian (kategori dan subkategori) dari sumber data primer dan sekunder sebagai hasil penelitian (Sugiyono dalam Taufan, 2016). Adapun langkahlangkah yang dilakukan sebagai berikut:

1. Reduksi data. Informasi wawancara yang diperoleh dari sejumlah informan dicatat dan dituangkan dalam bentuk catatan deskripsi hasil wawancara. Data yang telah dicatat dan ditabulasi diseleksi, sehingga yang diambil hanya yang dianggap paling representative untuk disajikan sebagai data.

2. Penyajian dan pengolahan data. Data yang telah diseleksi diinterpretasikan dan direlevansikan dengan data etik dan emik. Informasi yang diperoleh dari wawancara diinterpretasikan untuk memberikan gambaran/mendeskripsikan focus-fokus masalah.

3. Penarikan kesimpulan. Mendeskripsikan focus masalah yang sudah diinterpretasi dan dilakukan penarikan kesimpulan. Kesimpulan sementara direlevansikan dengan hasil observasi lapangan, sehingga diperoleh pemahaman masalah yang sesuai dengan kajian teoris. Melakukan penyimpulan akhir dan mendeskripsikannya sebagai hasil penelitian.

\section{HASIL PENELITIAN DAN PEMBAHASAN}

1. Data Informan Penelitian.

Peneliti menggunakan panduan wawancara dengan 19 pertanyaan dan waktu yang dibutuhkan 5-10 menit.Berikut adalah data yang menunjukkan deskripsi subjek penelitian:

Tabel 1. Deskripsi Data Informan

\begin{tabular}{|c|c|c|c|}
\hline NO. & Inisial & Umur & Mulai Merokok \\
\hline 1. & VT & 16 & "dari kelas 3 SMP." \\
\hline 2. & FS & 16 & 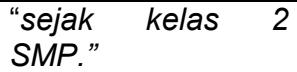 \\
\hline 3. & SR & 17 & 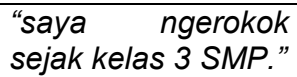 \\
\hline 4. & EN & 16 & $\begin{array}{l}\text { "eh mulai kelas } 1 \\
\text { SMP-an lah." }\end{array}$ \\
\hline 5. & $A D$ & 17 & $\begin{array}{l}\text { "sejak kelas } 3 \text { SMP } \\
\text { sih." }\end{array}$ \\
\hline 6. & $\mathrm{IM}$ & 17 & $\begin{array}{l}\text { "dari umur berapa } \\
\text { yah..kelas } 3 \text { SMP } \\
\text { lah" }\end{array}$ \\
\hline 7. & RA & 18 & $\begin{array}{l}\text { "saya merokok tuh } \\
\text { dari kelas 9." }\end{array}$ \\
\hline 8. & RT & 18 & $\begin{array}{l}\text { "sejak umur } 14 \\
\text { tahun teh, kelas } 2 \\
\text { SMP." }\end{array}$ \\
\hline 9. & AN & 18 & $\begin{array}{l}\text { "waktu SMP kelas } \\
\text { 2." }\end{array}$ \\
\hline 10. & TN & 18 & "kelas 3 SMP lah." \\
\hline
\end{tabular}

Sumber: Data Primer

\section{Gambar 1. Rata-Rata Usia Informan}

\section{Frekuensi}

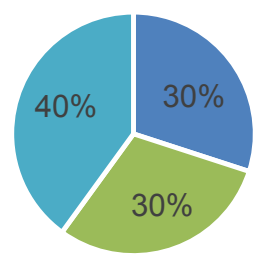

- 16 Tahun - 17 Tahun - 18 Tahun

Sumber: Data Primer

Gambar 2. Informan Mulai Merokok

\section{Frekuensi}

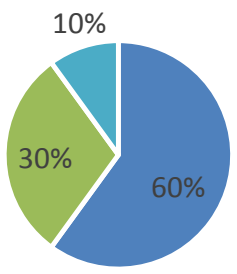

- Kelas 3 SMP - Kelas 2 SMP -Kelas 1 SMP

\section{Sumber: Data Primer}

Gambar 1 dan 2 memperlihatkan gambaran usia dan kelas informan mulai merokok. Frekuensi informan merokok sebesar $40 \%$ berusia 18 tahun, 30\% 16 tahun, dan $30 \% 16$ tahun. Sementara $60 \%$ informan mulai merokok saat kelas $3 \mathrm{SMP}$, $30 \%$ saat kelas 2 SMP, dan $10 \%$ saat kelas 1 SMP. Hal ini memperlihatkan bahwa remaja paling banyak mulai merokok saat kelas 3 SMP.

Seorang remaja sudah tidak lagi dapat dikatakan sebagai kanak-kanak, namun masih belum cukup matang untuk dikatakan dewasa. Mereka sedang mencari pola hidup yang sesuai dan ini sering dilakukan melalui metode coba-coba walapun metode coba-coba ini mengalami banyak kesalahan, kesalahan yang dilakukan sering menimbulkan kekuatiran serta perasaan yang tidak menyenangkan bagi lingkungan sekitar (Sebayang, 2018).

Merokok biasanya mulai dilakukan selama masa kanak-kanak dan masa remaja. Yang mana masa remaja sering disebut dengan istilah masa storm and 
stree di mana terjadi pergolakan emosi yang diiringi dengan pertumbuhan fisik yang pesat dan pertumbuhan secara psikis yang bervariasi. Masa remaja yang identik dengan lingkungan sosial tempat berinteraksi, membuat mereka dituntut untuk dapat menyesuaikan diri secara efektif. Apabila lingkungan tidak mampu memenuhi gejolak energy remaja maka akan memicu luapan kelebihan energy, dan sering kali remaja melampiaskan dengan hal negative misalnya melakukan pengrusakan sarana umum dan merokok (Tridhonanto, 2010).

Hal tersebut sejalan dengan dengan pandangan Surbakti (2011), dengan merokok para remaja tersebut merasa bahwa mereka dapat menghilangkan ketegangan atau kegelisahan yang ditimbulkan oleh tekanan perubahan yang mereka alami. Dengan merokok, mereka merasa senang, tenteram, aman, nyaman sehingga emosi mereka terkendali.

Kegiatan merokok yang dilakukan oleh remaja yang biasanya dilakukan di depan orang lain, terutama dilakukan di depan kelompoknya karena mereka sangat tertarik kepada kelompok sebayanya atau dengan kata lain terikat dengan kelompoknya (Wahyudi, dkk., 2017).

2. Orang Tua Informan yang Merokok.

Gambar. 3. Gambaran Orang Tua Informan yang Merokok.

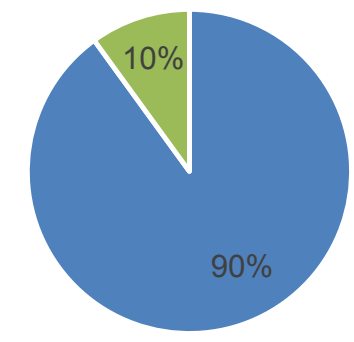

- Merokok - Tidak Merokok

Sumber: Data Primer.

Pada gambar 3 menunjukkan gambaran orang tua informan yang merokok sebesar $90 \%$ dan tidak merokok 10\%. Dalam penelitian (Safitri, dkk., 2013) menyatakan, semakin tinggi authoritative parenting (pola asuh orang tua) maka semakin tinggi perilaku merokok remaja. Hal ini mingkin terjadi sebab pengasuhan authoritative parenting hanya memberikan batasan dan mengendalikan perilaku remaja saja, tetapi yang memutuskan perilaku tersebut adalah remaja itu sendiri.

3. Saudara yang Tinggal Serumah dengan Informan yang Merokok.

Gambar 4. Saudara Informan yang Merokok.

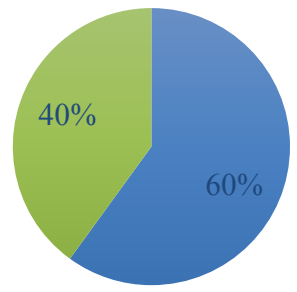

- Ada - Tidak Ada

Sumber: Data Primer.

Gambar 4 memperlihatkan gambaran saudara informan yang merokok $40 \%$ dan tidak merokok 60\%. Hasil penelitian Munir (2018) menyatakan, perilaku merokok didalam keluarga sangat mempengaruhi perilaku sebagian besar para remaja dalam memulai atau mencoba merokok pertama kalinya, kemudia mencoba merokok dalam beberapa waktu perbulan, sampai mengalami transisi dari merokok bulanan menjadi harian (merokok menjadi hal wajib dilakukan setiap hari).

4. Informan yang Terpengaruh dari Orang Tua, Saudara, dan Lingkungan Yang Merokok.

Gambar 5. Informan yang Terpengaruh dari Orang Tua, Saudara dan Lingkungan.

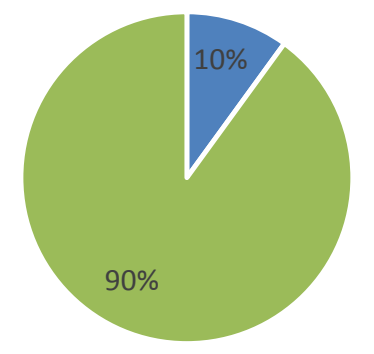

- Orang Tua - Lingkungan

Sumber: Data Primer.

Pada gambar 5 memperlihatkan, sebesar $90 \%$ informan terpengaruh dari lingkungan atau pergaulan teman dan $10 \%$ pengaruh dari orang tua. Dengan pengaruh dari lingkungan dan teman sebaya, para informan mulai merokok dan melanjutkan 
kebiasaan tersebut hingga saat ini. Berawal dari coba-coba dan di dorong rasa penasaran (Kurniafitri, 2015).

5. Orang Tua dan Guru yang Tahu Informan Merokok.

Gambar 6. Orang Tua dan Guru Tahu Informan Merokok.

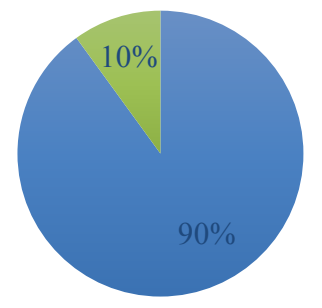

- Tahu Tidak Tahu

\section{Sumber: Data Primer.}

Gambar 6 menunjukkan gambaran orang tua dan guru yang tahu informan merokok sebanyak $90 \%$ dan tidak mengetahui informan merokok $10 \%$. Hal ini dikarenakan, para informan melakukan perilaku merokok di tempat tongkrongan bersama teman sebayanya. Salah satu fackor yang mempengaruhi remaja merokok, yaitu pengaruh teman. Berbagai fakta mengungkapkan bahwa semakin banyak remaja merokok maka semakin besar kemungkinan teman-temannya adalah perokok demikian sebaliknya (Hufron, 2010).

6. Informasi Bahaya Rokok yang Diketahui Oleh Informan.

Gambar 7. Informasi bahaya rokok yang diketahui oleh informan.

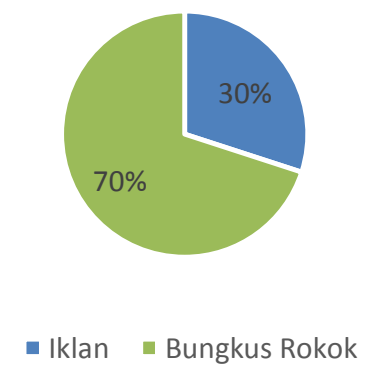

\section{Sumber: Data Primer}

Pada gambar 7 menunjukkan, $70 \%$ informan mengetahui informasi bahaya merokok dari bungkus rokok dan 30\% informan mengetahui dari iklan.

Meskipun bahaya merokok sudah tertera pada bungkus rokok dan iklan-iklan di TV, namun hal itu tidak membuat mereka berhenti merokok. Hasil penelitian dari (Harun, dkk., 2017) menyatakan, terdapat mispersepsi remaja terhadap iklan rokok.
Promosi bahaya rokok sebaiknya melibatkan tokoh-tokoh masyarakat dan sasaran promosi ditujukan pada kegiatankegiatan masyarakat. Pentingnya redesain iklan pada bungkus rokok. Desain iklan pada bungkus rokok harus mampu memberi kesan menakutkan

7. Alasan Informan Mulai Merokok.

Berdasarkan wawancara yang dilakukan terhadap ke 10 informan remaja putri mengenai awal mula merokok, didapati bahwa enam (6) orang karena "Teman" dan empat (4) orang mengatakan alsan "Penasaran", "Coba-coba", dan "Iseng".

Tabel 2. Alasan Informan Merokok.

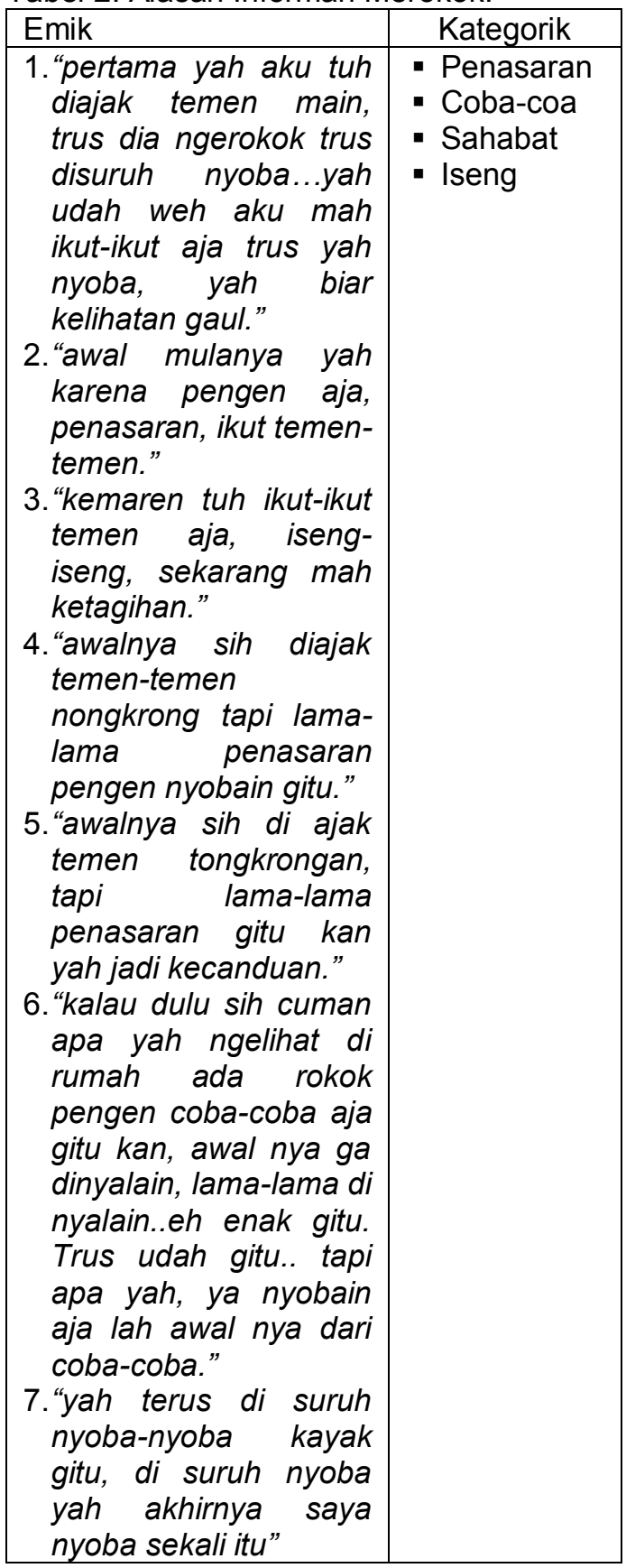




\begin{tabular}{|lr|}
\hline 8. “awal nya sih di ajak \\
teman tongkrongan, \\
tapi lama-lama \\
penasaran." \\
9."yah pertama di ajak \\
sama temen..ngeliat \\
temen juga banyak \\
yang ngerokok..terus \\
sama temen diajak." \\
10. "awal nya mah \\
sih di ajak temen- \\
temen di suruh \\
ngumpul..disuruh \\
coba-coba \\
doing..ngehirup \\
doang.... awal nya \\
mah emang ga enak \\
cuman makin sini \\
makin di tawarin \\
terus..makin \\
ketagihan." \\
\hline
\end{tabular}

\section{Sumber: Data Primer}

Berdasarkan tabel 2 diatas didapati bahwa alasan informan merokok dikarenakan pengaruh teman, ingin cobacoba, penasaran dan iseng.

Banyak sekali aspek yang menyebabkan para remaja menjadi perokok. Seperti yang dikemukakan oleh Surbakti (2011) beberapa diantaranya sebagai berikut:

a. Coba-coba. Pada umumnya, para remaja yang merokok mengaku bahwa awal mereka merokok adalah cobacoba. Pada masa coba-coba tersebut tidak ada yang melarang atau memperingatkan mereka tentang bahaya atau dampak merokok terhadap kesehatan. Akibatnya, mereka ketagihan atau kecanduan sehingga tidak mampu lagi menghentikannya.

b. Pengaruh teman-teman. Selain karena coba-coba, factor lain yang juga turut mendorong para remaja merokok adalah teman-teman. Teman-teman yang merokok, biasanya mendorong temannya yang lain untuk merokok. Demikian seterusnya sehingga kegiatan merokok sulit sekali dihentikan dikalangan para remaja, sebaliknya malah bertambah.

c. Pengaruh orang tua. Selain pengaruh teman-teman, maka para orang tua yang perokok merupakan pendorong atau penyebab utama anak-anak remaja mereka menjadi perokok. Hal ini dapat dipahami karena bagaimanapun para remaja tentu saja secara diam-diam atau sembunyi-sembunyi ingin mengetahui atau mencoba kenikmatan merokok yang setiap hari mereka saksikan dilakukan oleh orang tua mereka.

Berbagai fakta mengungkapkan bahwa semakin banyak remaja merokok maka semakin besar kemungkinan temantemannya adalah perokok juga dan demikian sebaliknya. Dari fakta tersebut ada dua kemungkinan yang terjadi, pertama remaja tadi terpengaruh oleh teman-temannya atau bahkan temanteman remaja tersebut dipengaruhi oleh diri remaja tersebut yang akhirnya mereka semua menjadi perokok. Di antara remaja perokok terdapat $87 \%$ mempunyai sekurang-kurangnya satu atau lebih sahabat yang perokok begitu pula dengan remaja non perokok Al Bachri (dalam Wahyudi, 2017).

Sama halnya dengan penelitan yang dilakukan oleh Ningrum, dkk. (2018) mengatakan perilaku merokok pada remaja terjadi karena adanya pengaruh dari lingkungan keluarga, lingkungan teman sebaya (peer group), serta pengaruh dari lingkungan sekolah (guru dan staff pengajar). Lestary (2012) dalam penelitian nya juga meyatakan, salah satu factor yang menyebabkan remaja putri untuk merokok berasal dari factor dimensi ektrinsik yaitu pengaruh teman sebaya.

8. Hal yang Dirasakan Informan Ketika Pertama Kali Merokok.

Dari hasil wawancara memperlihatkan mengenai gambaran tentang hal yang dirasakan oleh informan saat pertama kali merokok yaitu, pusing, batuk, pahit dan tidak enak.

Tabel 3. Hal yang dirasakan Informan ketika pertama kali merokok.

\begin{tabular}{|c|c|}
\hline Emik & Kategorik \\
\hline $\begin{array}{l}\text { 1."batuk-batuk, pusing } \\
\text { terus sesak ya kayak } \\
\text { gitulah." } \\
\text { 2. "ga enak sih, batuk- } \\
\text { batuk gitu, pusing } \\
\text { kepalanya, dadanya } \\
\text { yang kayak sesak gitu } \\
\text { gening." kali } \\
\text { 3. "pertama awalnya } \\
\text { ngerokok, atu } \\
\text { batuk-batuk ga enak." } \\
\text { 4. "batuk-batuk awalnya } \\
\text { mah." } \\
\text { 5. "batuk-batuk } \\
\text { awalnya mah". } \\
\text { 6. "awalnya sih langsung } \\
\text { batuk, udah gitu terus } \\
\text { serak terus agak } \\
\text { pusing weh gitu". }\end{array}$ & $\begin{array}{l}\text { - Batuk } \\
\text { - Pusing } \\
\text { - Pahit } \\
\text { - Tidak enak }\end{array}$ \\
\hline
\end{tabular}




\begin{tabular}{|l|}
\hline 7. "kayak pertama kali \\
ngisap gitu kayak \\
batuk-batuk gitu, \\
setelah beberapa \\
menit pusing ga jelas \\
gitu...yah batuk lah \\
pokok nya soalnya ga \\
kuat.tapi di suruh \\
nyoba lai-lagi sampai \\
habis sebatang." \\
8. "batuk-batuk, pusing, \\
gitulah awalnya." \\
9. "pahit kalau dirasa- \\
rasa, sama bbatuk- \\
batuk gitu..karena \\
asap nya ga enak." \\
10. "pertama nya \\
mah teh ga enak \\
gitu..apalagi asap nya \\
kan gitu.Cuma lama- \\
lama kesini kan jadi \\
kayak...ahh sambil \\
nyantai kan enak juga \\
kayak nya ngerokok \\
gitu teh." \\
\hline
\end{tabular}

Sumber: Data Primer

Tabel 3 memperlihatkan yang dirasakan informan saat pertama kali merokok adalah; "batuk-batuk" delapan (8) orang, "pusing" lima (5) orang, "tidak enak" tiga (3) orang dan yang terakhir mangatakan "pahit" satu (1) orang.

Dalam penelitian Trisnaniar (2015) menyatakan, pada saat mulai mencobacoba rokok, walaupun awalnya merasa tidak enak, pahit dimulut, atau merasa aneh, namum perokok pemula tetap mencobanya dan berlangsung terusmenerus. Rokok menimbulkan asap yang tidak sedap. Asap rokok dapat mengakibatkan sesak napas bahkan asap rokok membuat orang-orang batuk-batuk bila menghirupnya.

9. Bagaimana respon teman-teman mengetahui anda merokok?

Hasil wawancara terhadap informan, memperlihatkan respon temanteman mengetahui informan merokok; biasa saja, tidak merespon, dan tidak menyangka.

Tabel 4. Respon teman-teman mengetahui informan merokok.

\begin{tabular}{|l|l|}
\hline Emik & Kategorik \\
\hline 1."kalau yang temen & - Tidak \\
ngajakin ngerokok mah & merespon \\
betah-betah aja liat aku & - Biasa saja \\
sering merokok, tapi & - Tidak \\
kalau yang lain mah & menyangka \\
yang bukan se-geng & - Ngajakin \\
\hline
\end{tabular}

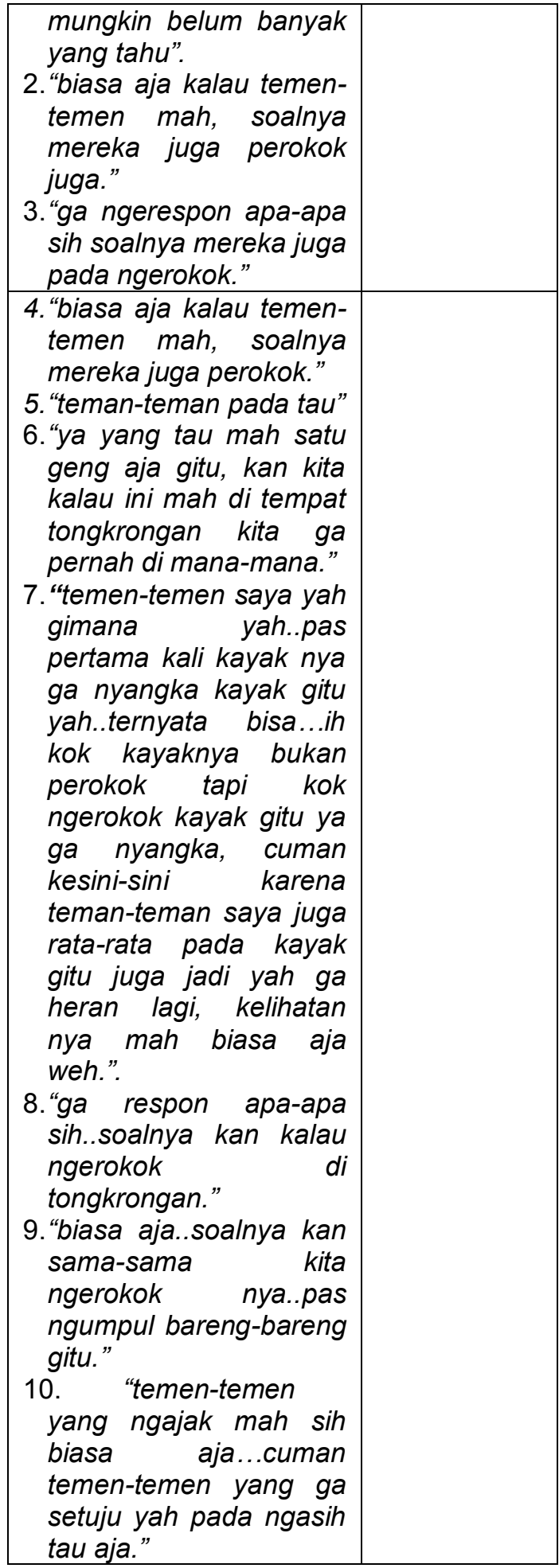

Sumber: Data Primer

Pada tabel 4 memberikan gambaran tentang respon teman-teman mengetahui informan merokok, yaitu; "tidak merespon" lima (5) orang, "biasa saja" empat (4) orang, "ngajakin" satu (1) orang, dan "tidak menyangka" satu (1) orang. Lemahnya sikap tak acuh yang ditunjukkan dalam lingkungan pertemanan, membuat para 
informan tetap melakukan aktivitas perilaku merokok.

Dalam penelitan (Rachmat, dkk., 2013) menjelaskan, kebutuhan untuk diterima sering kali membuat para remaja berbuat apa saja agar dapat diterima dikelompok-kelompoknya dan terbebas dari sebutan "pengecut". Remaja mengalami tekanan internal untuk merokok jika orang lain di sekitar mereka merokok.

10. Hal yang Dirasakan Informan Setelah Merokok.

Berdasarkan hasil wawancara yang dilakukan terhadap ke 10 informan didapati hal yang dirasakan setelah merokok yaitu; lima (5) orang merasakan "nyaman", dua (2) orang merasakan "enak", empat (4) orang "biasa saja" dan satu (1) orang merasakan "puas".

Tabel. 5 Hal yang dirasakan informan setelah merokok.

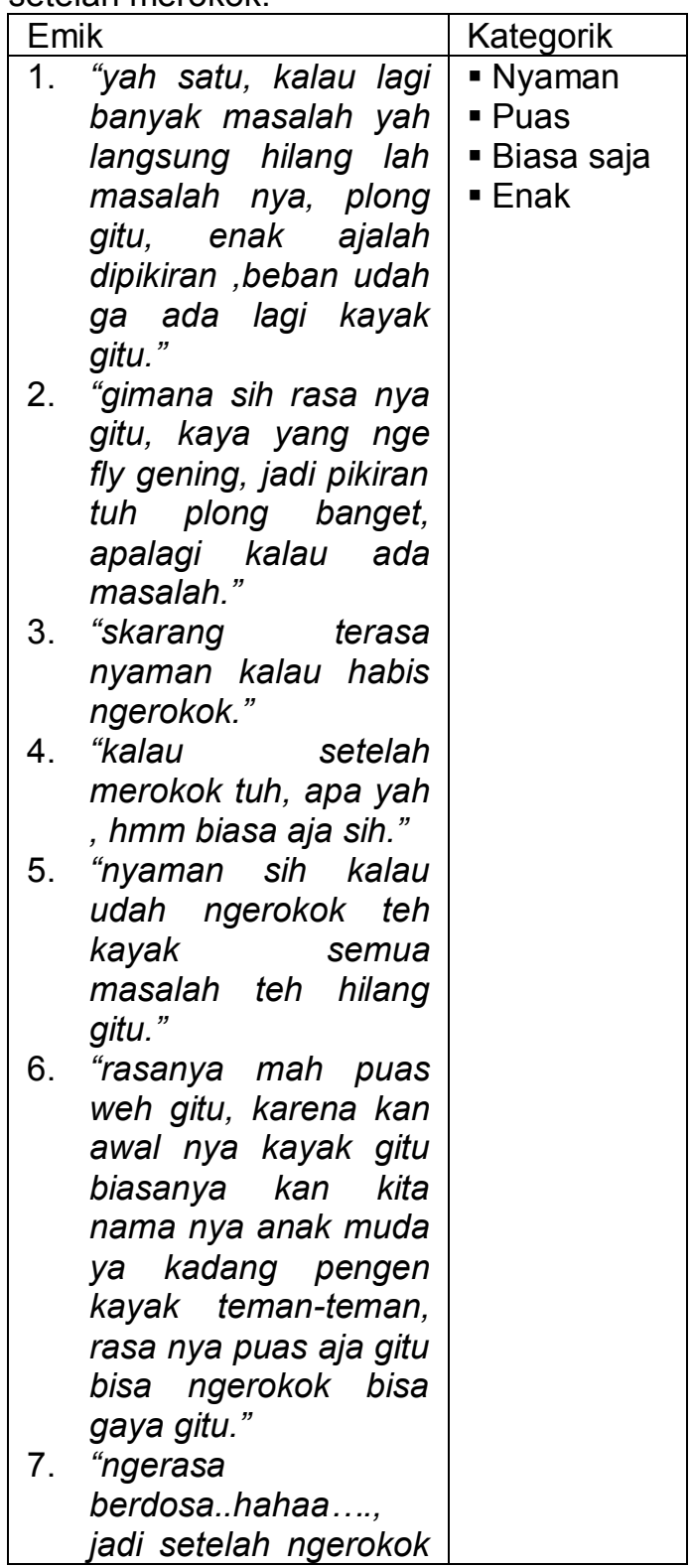

\begin{tabular}{|c|c|}
\hline 8. & 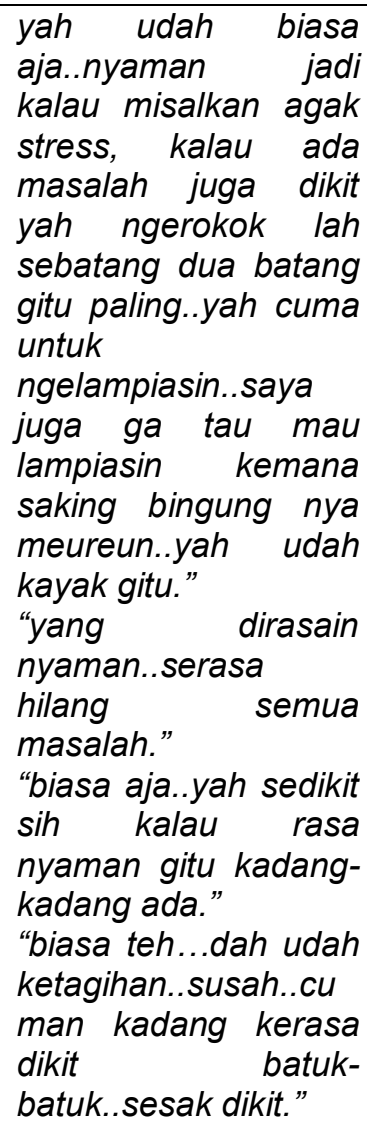 \\
\hline
\end{tabular}

Sumber: Data Primer

Berdasarkan tabel 5 diatas didapati hal yang dirasakan informan setelah merokok adalah nyaman, puas, enak, dan biasa saja.

Rokok dapat memberikan ketenangan, mengusir perasaan malas, menghilangkan sakit kepala dan stress karena nikotin adalah psikotropika stimulant. Timbulnya perasaan tenang, bebas stress, dan kreatif itu adalah reaksi positif dari psikotropika yang hanya berlaku bagi pencandunya. Namun, bagi yang bukan pecandu, efeknya tidak seperti itu. Efek positif itu hanyalah efek semu jangka pendek, sebab dalam jangka panjang pecandu rokok akan mengalami dampak buruk berupa ketagihan dan penyakit.

11.Apakah rokok sudah menjadi suatu kebutuhan bagi anda?

Hasil wawancara memperlihatkan tanggapan informan mengenai rokok sudah menjadi suatu kebutuahan antara lain; empat (4) orang mengatakan butuh saat "berkumpul bersama teman", empat (4) orang mengatakan butuh untuk "pelarian", "penghilang stress" dan "lagi santai" serta tiga (3) orang mengatakan rokok sudah menjadi "suatu kebutuahan". 
Tabel. 6 Rokok sudah menjadi suatu kebutuhan bagi informan

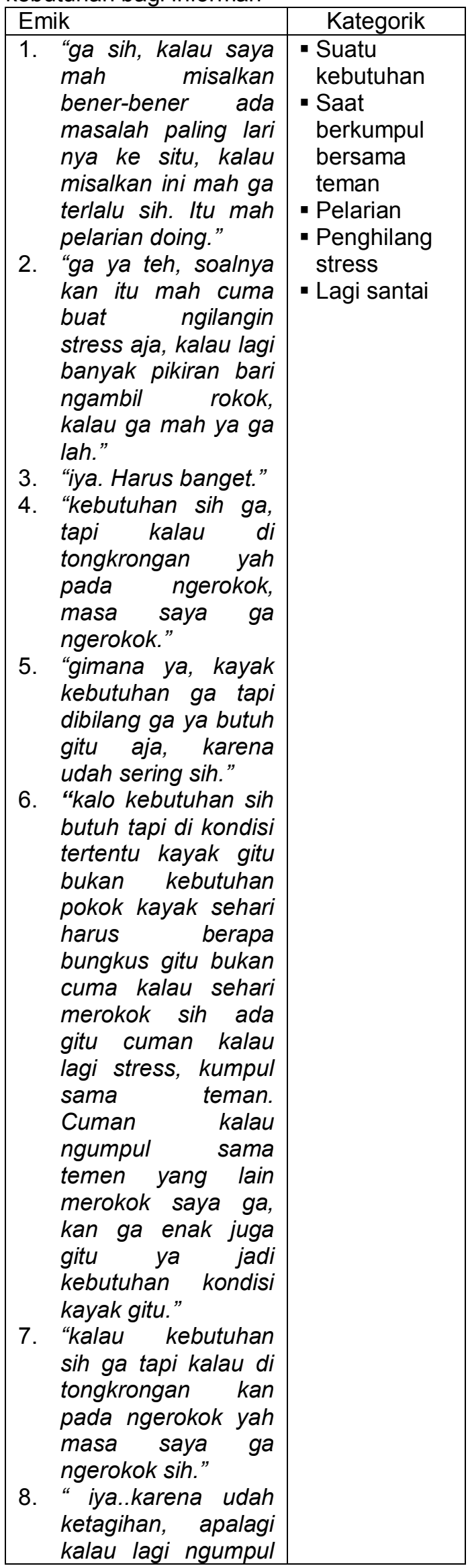

sama temen pasti

merokok."

9. "kebutuhan sih ga,

tapi kalau di

tongkrongan ada

ngerokok masa

saya ga ngerokok."

10. "ga sih teh, dah aku

mah paling kalau

lagi nyantai aja,

kalau lagi pengen

gitu ngerokok."

\section{Sumber: Data Primer}

Tabel 6 memperlihatkan tanggapan informan mengenai rokok sudah menjadi suatu kebutuhan adalah; sebagai pelarian, penghilang stress, lagi santai, dan saat berkumpul bersama teman serta rokok sudah menjadi suatu kebutuhan.

Nikotin yang terkandung dalam rokok merupakan bahan yang dapat menyebabkan adiksi atau ketergantungan. Toleransi terhadap nikotin mulai berkembang pada saat dosis pertama, oleh karena itu si pemakai terus menambah dosis untuk mempertahankan efek dan mencegah hilangnya gejala. Dosis pertama nikotin memberi perasaan segar atau waspada sedangkan dosis selanjutnya menimbulkan perasaan tenang dan rileks (Sudiono, 2008).

12.Bagaimana pandangan anda terhadap remaja putri yang merokok?

Berdasarkan hasil wawancara didapatkan, bahwa para informan memiliki pandangan terhadap remaja putri yang merokok yaitu; "biasa saja", "illfeel", "tidak baik" dan "jelek".

Tabel 7. Pandangan informan terhadap remaja putri yang merokok

\begin{tabular}{|l|l|}
\hline Emik & Kategorik \\
\hline 1. "ya ilfeel juga sih liat & - Biasa saja \\
nya tapi kalau ga & - Illfeel \\
ngerokok ya kayak & - Tidak baik \\
yang misalkan ada & - Jelek \\
masalah gitu ya ga & \\
enak we, jadi terasa & \\
ada beban terus." & \\
2. "sebenarnya sih ga & \\
suka yah jelek & \\
banget kalau dilihat & \\
kelihatan nya itu jadi & \\
kayak anak nakal \\
gitu kesannya, \\
meskipun kita ga tau \\
ya sebenarnya dia \\
itu ngerokok alasan \\
nya apa kan ga tau \\
tapi kelihatan nya & \\
\hline
\end{tabular}




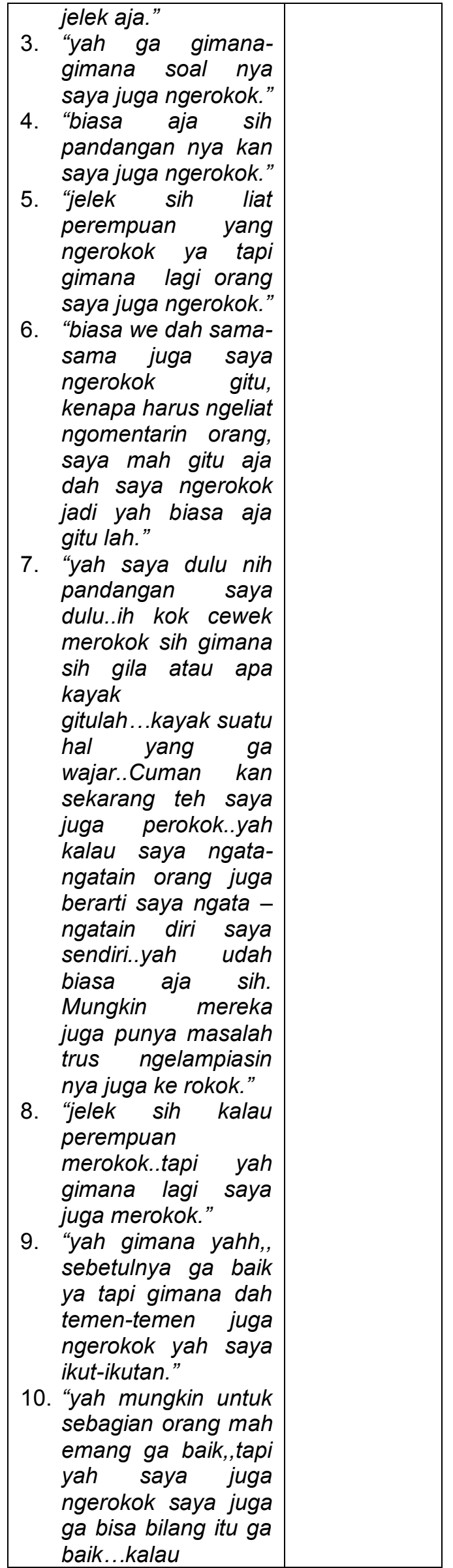

\begin{tabular}{|l|l|}
\hline $\begin{array}{l}\text { ketagihan } \text { mah } \\
\text { susah teh." }\end{array}$ & \\
Sumber: Data Primer \\
Pada tabel 7 pandangan informan
\end{tabular}
tentang remaja putri yang merokok mengatakan "biasa saja" empat (4) orang, "tidak baik" dua (2) orang, "illfeel" satu (1) orang dan "jelek" tiga (3) orang. Para informan tidak menunjukkan pertentangan terhadap perilaku merokok yang pada akhirnya membuat informan terus mempertahankan perilaku tersebut.

Dengan merokok para remaja merasa bahwa mereka dapat menghilangkan ketegangan atau kegelisahan yang ditimbulkan oleh tekanan perubahan yang mereka alami. Dengan merokok, mereka merasa tenang, tenteram, aman, nyaman sehingga emosi mereka terkendali. Para remaja tidak membutuhkan informasi yang menakutkan atau menakut-nakuti atau mengancam mereka. Sebaliknya, ,mereka membutuhkan informasi atau penjelasan yang rasional, ilmiah, masuk akal, logis disertai dengan keteladanan yang baik (Surbakti, 2011).

13. Apakah anda mempunyai keinginan untuk berhenti merokok? Jika ya, bagaimana usaha anda untuk mengurangi aktivitas merokok?

Hasil wawancara terhadap informan, menunjukkan keinginan dan usaha informan dalam mengurangi aktivitas merokok adalah; empat (4) mengatakan "mengurangi kumpul bersama teman perokok" empat (4) orang mengatakan menggantinya dengan "makan permen" satu (1) orang "mengurangi jumlah rokok" dan dua (2) orang mengatakan "belum ada keinginan".

Tabel 8. Keinginan dan usaha mengurangi aktivitas merokok

\begin{tabular}{|l|l|}
\hline Emik & Kategorik \\
\hline 1. "ada, tapi... & - Makan \\
paling, mungkin & permen \\
bisa aku ganti & - Mengurangi \\
buat makanan & jumlah \\
atau cemilan atau & rokook \\
yang lain biar ga & - Mengurangi \\
ngerokok." & kumpul \\
2. "pasti lah pengen & bersama \\
tapi untuk saat ini & teman \\
belum deh. Yah & - Belum ada \\
mendingan & keinginan \\
menjauh aja dari & \\
lingkungan yang & \\
seperti itu yah, \\
kayak temen- & \\
\hline \multicolumn{2}{|c}{} \\
\hline
\end{tabular}




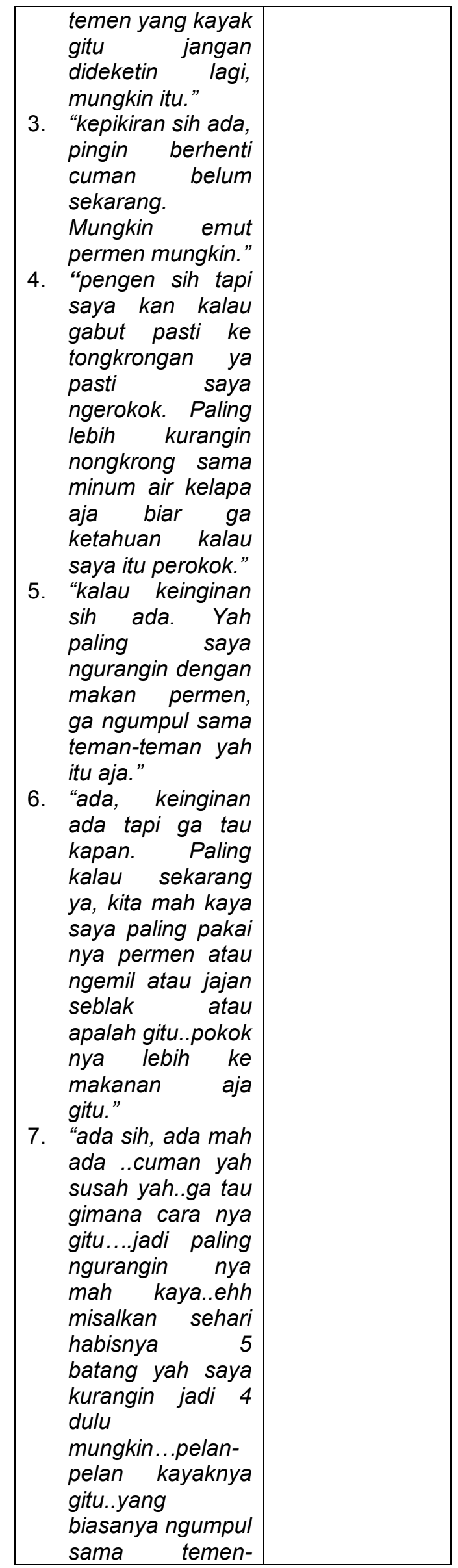

\begin{tabular}{|c|c|}
\hline 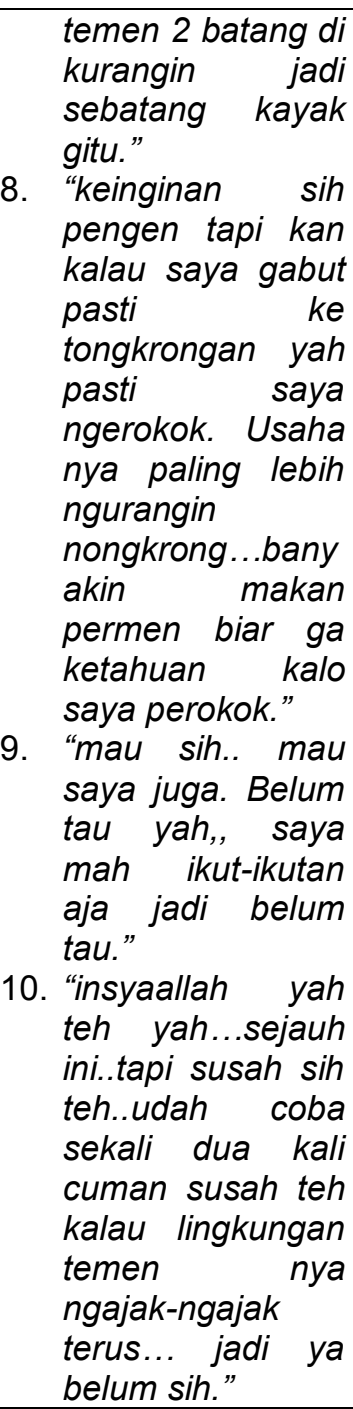 & \\
\hline
\end{tabular}

Sumber: Data Primer

Pada tabel 8 memperlihatkan adanya keinginan dan usaha informan dalam mengurangi aktivitas merokok yaitu, mengurangi berkumpul bersama teman perokok, menggantinya dengan makan permen, mengurangi jumlah rokok dan ada yang belum mempunyai keinginan untuk mengurangi aktivitas tersebut. Hanya saja, seluruh informan menyatakan bahwa keinginan tersebut tidak untuk dilakukan dalam waktu dekat ini. Kuat nya pengaruh dari lingkungan membuat para informan belum sepenuhnya ingin berhenti dari aktivitas merokok. Ditambah lagi kurangnya dukungan dari orang-orang terdekat seperti orang tua.

Mengurangi atau bahkan berhenti merokok, bukan sesuatu yang mudah dicapai. Perokok sudah paham betul tentang bahaya merokok, namun di sisi lain mereka juga memahami manfaat positif dari merokok, seperti menghilangkan stress 
yang dikemukakan dalam peneltian Sabarani (2018).

Hasil peneltian yang dikemukanan oleh Wulandari (2012) berhenti merokok bukan lah hal yang mudah. Banyak cara yang dapat dilakukan dalam usaha berhenti merokok, seperti komitmen, menggantikan rokok dengan permen, mengalihkan rokok dengan beraktivitas dan menghindari rokok serta memerlukan dukungan dari orang terdekat dan lingkungan yang sehat.

Untuk berhenti merokok, dibutuhkan komitmen yang kuat. Sebagaimana yang diungkapkan oleh Crofton (2009), beberapa orang merasa sulit untuk berhenti merokok dan sering di perlukan beberapa percobaan sebelum mereka berhasil. Angka kegagalan yang tinggi pada percobaan pertama untuk berhenti merokok dapat menimbulkan depresi baik bagi para perokok maupun orang-orang yang berusaha membantu berhenti merokok.

\section{KESIMPULAN}

1. Berdasarkan hasil penelitian yang telah diuraikan, usia informan yang mulai merokok terbanyak pada usia 15 dan duduk di kelas 3 SMP.
2. Hal yang menjadi alasan informan merokok yaitu; pengaruh teman, ingin coba-coba, penasaran dan iseng.

3. Hal yang dirasakan oleh informan saat pertama kali merokok yaitu, pusing, batuk, pahit dan tidak enak.

4. Respon teman mengetahui informan merokok yaitu; biasa saja, tidak merespon, dan tidak menyangka.

5. Hal yang dirasakan informan setelah merokok antara lain; nyaman, puas, enak, dan biasa saja.

6. Tanggapan informan mengenai rokok sudah menjadi suatu kebutuhan yaitu; sebagai pelarian, penghilang stress, lagi santai, dan saat berkumpul bersama teman serta rokok sudah menjadi suatu kebutuhan.

7. Pandangan informan terhadap remaja putri yang merokok yaitu; "biasa saja", "illfeel", "tidak baik" dan "jelek".

8. Ada keinginan dan usaha informan dalam mengurangi aktivitas merokok yaitu, mengurangi berkumpul bersama teman perokok, menggantinya dengan makan permen, mengurangi jumlah rokok dan ada yang belum mempunyai keinginan untuk mengurangi aktivitas tersebut.

\section{DAFTAR PUSTAKA}

Adian, G. H. (2013). Teknik Berargumentasi: Berpikir sebagai Kecakapan Hidup. Kencana: Jakarta.

Ali, M. (2009). Pikatlah Hatiku: 30 Bisikan Hati Isteri. PTS Millenia SDN.BHD: Kuala Lumpur

Crofton, J. D. (2009). Tembakau Ancaman Global.Kelompok Gramedia: Jakarta

Elon, Y., Evelin, M. (2019). Fenomena Merokok Pada Anak Usia Remaja: Studi Kualitatif. Klabat Journal of Nursing. Vol. 1 No.1: 78-87. Retrieved from: http://ejournal.unklab.ac.id/index.php/kjn/article/view/385

Handayani, A. (2012). Perempuan Berbicara Kretek. Indonesia Berdikari: Jakarta

Harun, C. L. (2017). "SAYA TIDAK TAKUT MATI" Mispersepsi Terhadap Iklan Bahaya Merokok di Ponorogo. Indonesia Journal for Health Sciences. Vol 01. No.02: 14-20.

Hufron, S. (2010). Mengenal Bahaya Rokok Bagi kesehatan. Penerbit Horozon: Bogor

Kurniafitri, D. (2015). Perilaku Merokok Pada Perempuan Di Perkotaan (Studi Kasus Mahasiswi Di Kota Pekanbaru). IOM FISIP UR. Vol. 2 No.2:1-15.

Lestary, D. (2012). Gambaran Faktor-Faktor Yang Mempengaruhi Remaja Putri Untuk Merokok. Jurnal Penelitian dan Pengukuran Psikologi. Vol.1. No.1: 46-54.

Lutfiyah, F. \&. (2017). Metodologi Penelitian: Penelitian Kualitatif, Tindakan Kelas dan Studi Kasus. CV Jejak: Jawa Barat.

Martini, S. (2014). Makna Merokok pada Reamaja Putri Perokok. Jurnal Psikologi Pendidikan dan Perkembangan. Vol.3. No.2: 119-127.

Munir, M. (2018). ). Pengetahuan Dan Sikap Remaja Tentang Risiko Merokok Pada Santri Mahasiswa Di Asrama UIN Sunan Ampel Surabaya. Jurnal Sains, Fakultas Sains dan Teknologi. Vol.1 No.2: 93-104.

Ningrum, A. I. (2018). Kajian Sosiologi Tentang Fenomena Perilaku Merokok Siswa di Madrasah Tsanawiyah ALAmin Tabanan. Jurnal IImiah Sosiologi. Vol. 1 No.02: 1-110. 
Organization, W. H. (2015). WHO report on the global tobacco epidemic: Raising taxes on tobacco. World Health Organization, 52-53. https://doi.org/ISBN 9789240694606.

Partodiharjo, S. (n.d.). Kenali Narkoba \& Musuhi Penyalahgunaannya. 2010: Esensi: Jakarta.

Rachmat, M. R. (2013). Perilaku Merokok Remaja Sekolah Menengah Pertama. Jurnal Kesehatan Masyarakat Nasional. Vol. 7 No.11: 502-508.

Rahman, T. (2018). Aplikasi Model-Model Pembelajaran dalam Penelitian Tindakan Kelas. CV Pilar Nusantara: Jawa Tengah.

RI, K. (2018). Riset Kesehatan Dasar; RISKESDAS: Jakarta.

Rochka, M. A. (2019). Kawasan Tanpa Rokok di Fasilitas Umum. Uwais Inspirasi Indonesia: Jawa Timur.

Rukajat, A. (2018). Pendekatan Penelitian Kualitatif: Quantitatif Research Approach. Deepublish: Yogyakarta.

Sabarani, R. Y. (2018). Persuasi, Perilaku Merokok, dan Preferensi Anak Muda Terhadap Pesan Kampanye Berhenti Merokok. Jurnal ASPIKOM. Vol.3. No.5: 986-1001.

Safitri, A. M. (2013). Faktor-Faktor yang Mempengaruhi Perilaku Merokok Pada Remaja. Journal of Psychology. Vol. 18. No.1: 47-65.

Sebayang, W. D. (2018). Perilaku Seksual Remaja. Deepublish: Yogyakarta.

Sudianto, J. (2008). Pemeriksaan Patologi Untuk Diagnosis Neoplasma Mulut. EGC: Jakarta.

Sukmana, T. (2011). Mengenal Rokok dan Bahayanya. Kelompok Gramedia: Jakarta.

Surbakti. (2011). Question and Answer Teenagers. Kelompok Gramedia: Jakarta.

Surya, H. (2010). Jadilah Pribadi yang Unggul. Kelompok Gramedia: Jakarta.

Taufan, B. (2016). Sosiologi Hukum Islam: Kajian Empirik Komunitas Sempalan. Deepublish: Yogyakarta.

Tobacco Control Support Center-Ikatan Ahli Masyarakat Indonesia. (2018). Hubungan Terpaan Iklan, Promosi, Sponsor Rokok dengan Status Merokok di Indonesia.

Tridhonanto, A. B. (2010). Meraih Sukses dengan Kecerdasan Emosional. Kelompok Gramedia: Jakarta

Trisnaniar, I. (2015). Studi Fenomenologi: Intensi Merokok Pada Remaja. NASKAH PUBLIKASI. SKRIPSI.

Wahyuni, I. B. (2017). Bahasa Indonesia Kesehatan. Andi: Yogyakarta

WHO. (2015). WHO report on the global tobacco epidemic: Raising taxes on tobacco. World Health Organization, $52-53$.

Wulandari, I. A. (2012). Pengalaman Merokok Pada Mantan Perokok. JURNAL NURSING STUDIES. Vol. 1 No.1: $36-42$. 